\title{
OBSERVATIONS ON THE EUCALYPTS OF NEW SOUTH WALES.
}

\section{PART VII.}

By Henry Deane, M.A., and J. H. Maiden.

(Plates v.-vii.)

Eucalyptus affinis, sp.nov.

(Plate v.)

A tree of moderate size, attaining a height of 80 feet, and a diameter of 2 feet 6 inches.

Vernacular names.- "Tallow Wood" at Murrumbidgerie, owing to the greasy nature of its wood, and "Black Box" at Stuart Town; "White Ironbark" and "Ironbark Box" at Grenfell and above Mt. Macdonald, at the junction of the Abercrombie and Lachlan Rivers, according to Mr. Cambage ; "Bastard Ironbark" at Minore (J. L. Boorman).

Our first complete series of specimens were received from Mr. Andrew Murphy in October, 1899. Mr. J. L. Boorman collected it in February, 1899.

Bark - To quote from a letter by Mr. R. H. Cambage :- "In appearance it looks half Ironbark and half Box, and has strong affinities to both. Often the butt in old trees is nearly as rough as that of $E$. sideroxylon, but seldom quite, while the upper part resembles E. albens; but in general it has a dark brown, fairly rough bark an inch thick, and is easily distinguished from the other trees. The bark is thinner and softer than E. sideroxylon, but harder and thicker than E. albens."

Timber.-Of a medium brown colour, inlocked, hard and tough, greasy to the touch, better esteemed than the wood of either $E$. hemiphloia or E. sideroxylon, among which it grows. It is used for railway sleepers, dray shafts and general wheelwright's work, according to Mr. R. H. Cambage. 
Sucker leaves - Alternate, ovate, obtuse, slightly emarginate and mucronate (in our specimens); about 3 inches long by $1 \frac{3}{4}$ broad; intramarginal vein at a considerable distance from the edge.

Mature leaves. -Lanceolate, slightly falcate; pale-coloured, dull on both sides, rather coriaceous, usully 2 to 3 inches long; veins at an angle of about $30^{\circ}$ with the midrib, but inconspicuous except the midrib and the thickened margin; intramarginal vein inconspicuous and at some distance from the edge.

Peduncles axillary, flattened at first but nearly terete when the fruit is ripe; with 3 to 7 flowers.

Buds. - Shaped like a tip-cat, to use a homely expression, i.e., tapered equally towards base and operculum; somewhat angular, the operculum attenuate. Calyx-tube likewise attenuate, tapering into a short pedicel. Anthers in the bud all folded; stamens white, the outer ones seemingly all fertile; anthers opening in terminal pores. Style and stigma as figured at fig. 6, E. hemiphloia, in the Eucalyptographia.

Fruits.-Ovate-truncate, tapered at the base, somewhat contracted at the orifice, about 3 lines in diameter, the rim narrow, slightly convex and dark-coloured; the capsule depressed.

Range.-Between Wellington and Dubbo, towards Molong and Parkes, Grenfell, and in other parts of the Western districts.

The species appears to possess resemblances to the imperfectly known Ironbark, E. drepanophylla, F.v.M. The fruits of the latter are, however, sub-cylindrical, the orifice not constricted, the rim different and the valves slightly exserted when the capsule is perfectly ripe; the leaves are narrower and the veins finer and more parallel. Further observations on this head may be deferred until $E$. drepanophylla is more perfectly known.

The true affinities of our species are, in our opinion, with $E$. sideroxylon, A. Cunn., and E. hemiphloia, F.v.M. Roughly speaking, it resembles the inflorescence of $E$. hemiphloia, the fruits of $E$. sideroxylon, while its timber and bark partake of the characters of both.

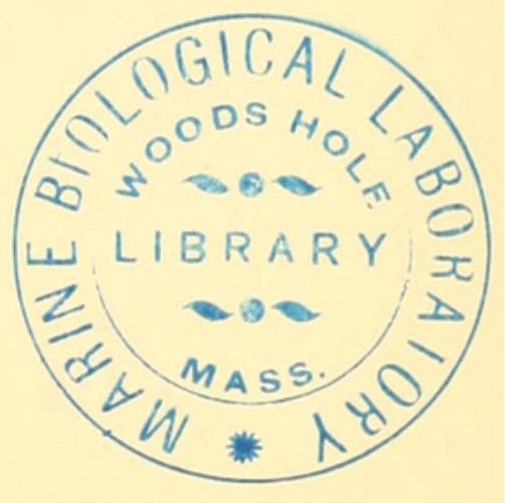


Mr. Cambage is of opinion that the tree is a hybrid between $E$. hemiphloia, v. albens, and E. sideroxylon, a view which had already occurred to us. It certainly seems only to be found when the other two trees are present. There are difficulties in the way of recognising hybridism in Eucalypts, and as we propose to treat this subject later on we refrain from being dogmatic on the present occasion.

Below we give an account of some trees which partake of the characters of both an Ironbark, probably in this case $E$. siderphloia, and a Box, E.hemiphloia, and here hybridism again suggests itself. It is curious that in E. affinis we have a tree also partaking of the characters of an Ironbark and a Box, but in this case $E$. sideroxylon and E. hemiphloia, var. albens, apparently combine.

In view of the imperfect evidence of hybridisation before us we think it safer to give to E. affinis specific rank.

\section{Eucalyptus Cambagei, sp.nov.}

\section{(Plates vi.-vii.)}

A small or medium-sized tree.

Vernacular names._- "Bundy" of Burraga, Rockley and some other places; called also "Bastard Apple, "Bastard Box," and "Grey Box" in different localities throughout the Bathurst and Orange districts. The glaucous form is "Rough-barked Mountain Apple." See Part v. of this Series (Proceedings, 1899, p. 463), under E. goniocalyx.

Bark - A fibrous matted bark of a dirty grey colour, intermediate in character between that of $E$. Stuartiana and that of $E$. hemiphloia; the rough bark extending to the tips of the branches.

Timber.-Wood pale-coloured, apparently tough, but very little definite information concerning it is available. It is hard and is used extensively for fuel for copper furnaces at Burraga according to Mr. Cambage.

Sucker leaves. - Strictly opposite, later becoming alternate, very broad (up to 5 inches broad and 5 inches long), nearly orbicular 
and even emarginate, also cordate and passing in later growth through all the stages of broad-lanceolate to lanceolate, very glaucous. The sucker leaves have been confused with those of E. dives; the latter are, however, more acuminate and possess a stronger odour of peppermint. The sucker stems are markedly round.

Mature leaves._Lanceolate, more or less falcate, generally very long, up to 8 or 10 inches, usually pale-coloured, with the pellucid dots rather conspicuous (as in E.goniocalyx), usually more or less besprinkled with small blackish dots (as in the case of E. goniocalyx, E. Stuartiana and other species); veins oblique and numerous, but not close, at an angle of about 30 to $40^{\circ}$ with the midrib; the intramarginal one at a distance from the edge.

Buds.-Sessile, the peduncles short, thick and flat, each with three to seven or more flowers. For a figure of some buds see fig. 2, plate xli., Proceedings, 1899.

Calyx-tube 3 to 4 lines long, about 2 to $2 \frac{1}{2}$ lines in diameter, with 2 to 4 prominent angles; operculum shortly pointed or hemispherical, much shorter than the calyx-tube. Stamens about 3 lines long, folded in the bud.

Fruits._Ovoid or broadly ovoid, truncate valves generally well exserted (as at fig. 1 of plate xli., Proceedings, 1899), more so than E. goniocalyx. In the var. pallens the valves are apparently not so much exserted.

Range.-It is found in the southern districts (see localities under var. pallens, Part v. p. 463, 1899). It has not been found on the Blue Mountains, though very close to them (e.g., at Hassan's Walls, J.H.M.). It occurs as far west as Mt. Bulaway (3,450 feet, Coonabarabran district; W. Forsyth). It is common in the Bathurst and Orange districts, and possibly it may be found on any of the ranges lying between the southern and western railway lines of the colony.

Affinities.-Its affinities are undoubtedly with E. goniocalyx in the first place, and E. Stuartiana in the second. There is not the same tendency to confusion of this species in the field with $E$. goniocalyx as with E. Stuartiana, which in bark and general 
growth it resembles. The peduncles of $E$. Cambagei are shorter, thicker and flatter than those of E. goniocalyx usually are, not to mention other differences. It may be compared with an interesting form of E. goniocalyx from Mt. Wilson and other places in the Blue Mountains with peduncles often 1 inch in length, with smaller and often spreading calyx, valves much exserted, and with pointed buds.

The leaves of $E$. Cambagei are usually much longer than those of E. Stuartiana and the tree is easily distinguished. The buds and fruit are quite distinct, as may be seen from the figure.

Mr. Cambage writes:- "A typical Bundy grows on Silurian slate ridges, though it will also grow on hills of igneous rock, but in such cases the wood seems to me to be slightly softer, and in more than one instance I have noticed that the inflorescence seems better, the flowers more numerous, when the trees grow on slate ridges. The Apple (E. Stuartiana) grows on the flats and near creeks and thins out towards the top of a hill, giving place to the Bundy, and bushmen have argued with me that the tree simply goes by easy gradations from soft Apple on the low lands to hard Bundy on the high. I am satisfied that this is not so, as I have followed the Apple till it ceases up the side of a hill and it does not change, while the Bundy begins at once as a hard wood. By special search I have found more than once the top Apple on the side of a hill just above the lowest Bundy. In the month of October at Orange the buds of the Bundy were just opening into flowers, but I failed to find even one Apple bud or flower, as the flowering was over and the fruits well formed."

E. Cambagei is frequently quite glabrous, but it is often more or less glaucous, and in some localities even white. The latter form is Baron von Mueller's E. goniocalyx var. pallens (B.Fl. iii. $230)$.

Eucalyptus stricta, Sieb.

(For a previous reference see Proceedings, 1896, p. 708).

We have received this species from Mr. R. H. Cambage from the top of Pigeon-house Mountain (2360 feet), near Milton. It 
is known locally as "White Ash;" its fruits are nearly sessile and usually in threes. The only other Eucalypt growing with it on the very summit is E. Sieberiana, F.v.M. We have also received,

(a) From Mr. A. Murphy in November, 1899, collected from the top of the Penang Range, near Gosford, specimens of a tree very like a "Peppermint" in appearance, but having more flaky bark on the trunk and white smooth limbs. The fruit is like that of E. homastoma in shape, but the rim is sunk as in E. stricta. The trees, which are not abundant, show a transition towards E. homastoma, but we consider they should be grouped under E. stricta.

(b) From Mr. R. H. Cambage we have also received specimens which we take to be a somewhat aberrant form of E. stricta. The tree has the appearance of a "Peppermint." The base of the capsule is remarkably constricted, the whole being pear-shaped; the rim is broad and somewhat sunk. The specimens were collected in January, 1900, at Burrill, Milton, and on Pigeonhouse Mountain, Milton, about 100 feet from the summit.

\section{Eucalyptus eugenioides, Sieb.}

(For a previous reference, see Proceedings, 1896, 803.)

"Bastard Stringybark" (Penrith; J. L. Boorman, January, 1900). We desire to invite attention to an interesting form of this species. The opercula are more pointed; the fruits are smaller than is usual and nearly globular. They are on nearly filiform pedicels of about 2 lines; the common peduncle is twice that length and more. The plant is indubitably E. eugenioides, though from examination of the fruits alone it might reasonably be supposed to be E. hamastoma, var. micrantha.

Eucalyptus Stuartiana, F.v.M., var. Parviflora, var.nov.

(For a previous reference, see Proceedings, 1899, 628.)

It seems desirable to indicate, by some name, a small-fruited form of E. Stuartiana which has been found near Hassan's Walls, at Young, and in several other parts of the colony. The sucker or 
seedling-foliage is small, very glaucous, cordate and stem clasping; the fruits resemble those of a small-fruited form of E. tereticornis as much as that of E. Stuartiana, but the buds and timber sharply separate it from the former, and there is no doubt that it is referable to the latter species.

\section{Eucalyptes squamosa, D. \& M.}

(For a previous reference, see Proceedings, 1897, 561; 1899, 629.)

Upper Bankstown and Cabramatta (J. L. Boorman; February, 1900).

Eucalyptus quadrangulata, D. \& M.

(For a previous reference, see Proceedings, 1899, 451.)

Tillowrie, Milton (R. H. Cambage; January, 1900); the second locality for this rare species.

\section{Eucalyptus pulverulenta, Sims}

(For a previous reference, see Proceedings, 1899, 465.)

This species is widely diffused in the Goulburn district, but is so rare in the Western district that it is usually looked upon as exclusively Southern. Yet.Allan Cunningham collected it at Cox's River on 8th October, 1822, and noted it in his journal as " a large shrub about 8 feet high, and a species of Eucalyptus allied to E. corrata, Labill." He named it E. pulvigera. Mr. R. H. Cambage has recently found it at Apsley, near Bathurst. He says: "Height 10 to 30 feet, diameter 3 inches. Most of the buds have a small outer or double operculum. Fruits and buds in threes, cruciform. Growing on south side of hill, micaschist formation." Mueller (Fragm. ii. 70) gives "Lachlan River towards Bathurst" as a locality, but we have not yet received any from that district.

In the Goulburn district, in the month of March, we have seen on the same branch leaves of var. lanceolata, Howitt, plentifully admixed with leaves of the ordinary shape. The variety lanceolata, therefore, has no real existence, and must fall. We may 
mention that a young tree, bearing a profusion of lanceolate leaves, very glaucous, being almost white and even silvery, and gracefully pendulous, is one of the most beautiful plants we have, and a fit emblem of purity.

On Apparent Hybridisation between $E$ siderophloia, Benth., AxD E. hemiphloia, F.v.M.

For many years certain trees partaking of the characters of both the above have been known to local residents in the County of Cumberland, and have received distinctive names. The Riev. Dr. Woolls (Proceedings, v. 504) has drawn attention to them. We have specimens selected from six different trees, which we may call $a, b, c, d, e$ and $f$, and will describe their characteristics.

The anthers of $a$ and $b$ doubtless are like var. E. siderophloia; these open in parallel slits, not in pores as do those of $c, d, e$, and $f$.

(a) is the normal E. siderophloia, Benth. The tree grows pretty plentifully throughout the Bankstown and Cabramatta district, and is the only form recognised as Ironbark by the residents. The fruit is a little shorter and broader than that figured in the Eucalyptoyraphia.

b) is the Black Box of the Bankstown and Cabramatta district. Mr. J. L. Boorman describes the bark as rough (somewhat like Box), but sometimes it is scaly; the colour seems to vary considerably from black to pale brown. The timber is yellow and paler than that of $E$. siderophloia, interlocked in grain, exceptionally heavy and is very superior for all purposes; in the neighbourhood of Penrith it is sought after for making mauls. The buds are blunter than those of E. siderophloia, the anthers are similar, but the valves of the capsules are less exserted than those of $E$. siderophloia growing in the same district. The tree grows to a fair size, with long, pendulous, acuminate, glossy leaves.

In the specimens $c, d, e$ and $f$ the resemblance of flowers and fruit to $E$. hemiphloia is much greater than to E. siderophloia. The anthers open in pores, the fruits are broader and less cylin- 
drical, and the valves are scarcely exserted. The bark is, however, more of an "Ironbark" in character except in the case of $y$.

(c) is called "Bastard Box" or "Ironbark." It is found on the Waterloo Estate near Upper Bankstown and St. John's Park.

$(d)$ is "Bastard Box" or "Box." The trees are of large size, the bark rough to the tips of the branches.

(e) has a bark rougher than the preceding, but is otherwise identical.

(f) grows at Cabramatta and is called "Black Box" by Mr. T. Shepherd. The bark is fibrous and persistent, "the wood hard and bad for burning," according to the late Rev. Dr. Woolls. Dr. Woolls, who had an intimate and extensive knowledge of the Eucalypts of the colony, expressed himself to be much puzzled with these trees, and marked specimens of this particular form at one time as E. siderophloia and at another as E. paniculata. The original specimens are in the Herbarium of the Sydney Botanic Gardens and illustrate the difficulty that these supposed hybrids have given rise to in times gone by.

It will be seen how the above forms show different steps in the gradation between E. hemiphloia and E. siderophloia. A suspicion of a resemblance to $E$. sideruxylon is visible in at least one of the specimens. The case is very different in E. affinis, which, though partaking of some of the characters of E. hemiphloia var. albens and E. sideroxylon, is pretty constant in its amount of resemblance to each. The suggestion therefore that the trees last described and marked $b, c, d, e$ and $f$ are hybrids has much more force than in the case of E. affinis.

In describing E. Bosistoana, Mueller (Aust. Journ. of Pharmacy, Oct., 1895) included in it two trees, one the southern tree (a Red Box) with numerous valves and which is now generally recognised as E. Bosistoana. He also included the Ironbark Box of Cabramatta, a very different tree. One of us drew his attention to the matter and he promised to make the necessary amendment in the description, but death overtook him before he could carry out his intention. 
E. punctata, DC.

This tree is called "Black Box" at Capertee owing to the darkness of its bark. Specimens have been received from Mr. W. Heron, collected at Conjola. This is apparently the most southerly locality hitherto recorded. In the Flora Australiensis the species is stated to range as far north as the Macleay River. Most of the northern specimens are, however, our $E$. propinqua, allied to but now separated from $E$. punctata, DC. We have now received indubitable specimens of the latter from Mr. H. L. White collected on the main southern spur of the Wollooma Mountain in the Scone district, while Mr. W. Bäuerlen has collected it as far north as Lismore.

\section{EXPLANATION OF PLATES.}

Plate v.-E. affinis.

Fig. 1.-Sucker leaf.

Fig. 2.-Flowering twig.

Fig. 3.-Fruiting twig.

Figs. 4-7.--Fruits.

Fig. 8.-Stamens.

$$
\text { Plate vi.-E. Cambagei. }
$$

Fig. 1.-Flowering twig with leaves and fruits.

Fig. 2.-Twig with buds in various stages.

Figs. 3-5.-Fruits.

Figs. 6-7.- Stamens.

$$
\text { Plate vii.-E. Cambagei. }
$$

Figs. 1-2.-Sucker leaves; reduced in size. 


\section{$2 \mathrm{BHL}$ Biodiversity Heritage Library}

Deane, $\mathrm{H}$ and Maiden, J. H. 1900. "Observations on the eucalypts of New South Wales. Part VII." Proceedings of the Linnean Society of New South Wales 25, 104-113. https://doi.org/10.5962/bhl.part.12153.

View This Item Online: https://www.biodiversitylibrary.org/item/30484

DOI: https://doi.org/10.5962/bhl.part.12153

Permalink: https://www.biodiversitylibrary.org/partpdf/12153

\section{Holding Institution}

MBLWHOI Library

\section{Sponsored by}

MBLWHOI Library

\section{Copyright \& Reuse}

Copyright Status: NOT_IN_COPYRIGHT

This document was created from content at the Biodiversity Heritage Library, the world's largest open access digital library for biodiversity literature and archives. Visit BHL at https://www.biodiversitylibrary.org. 